\title{
TEUTONIC STATE ORDER'S CULTURAL HERITAGE IN TOWNS OF WARMIA-MASURIA PROVINCE IN POLAND
}

\author{
Łukasz Musiaka
}

\begin{abstract}
The area of contemporary Warmia-Masuria Province encompasses the major part of the monastic state of the Teutonic Knights, founded in the Middle Ages on the southern coast of the Baltic Sea. This area is unique because of the preserved cultural heritage. By conquering and inhabiting the Prussian tribes areas monks left behind their legacy. In the article, the author presents cultural heritage of 49 cities of Warmia-Masuria Province from the period of a monastic state. The article is divided into two parts. The first part describes the size and condition of preserved cultural heritage. The second is an overview of selected processes, conditions and problems associated with the use and protection of the Teutonic heritage of Warmia-Masuria Province.
\end{abstract}

Keywords: the Teutonic Knights, cultural heritage, Warmia, Masuria, Powiśle

\section{Introduction}

As a result of World War II, Poland greatly changed its territorial scope and boundaries. As compensation for the lands lost in the east, Poland obtained new areas, called the Recovered Territories, from the west to the north of "Interwar Poland" - the Second Polish Republic. The area of contemporary Warmia-Masuria Province, former Prussia area, also became part of Poland after World War II. The latest national rankings indicate that Warmia-Masuria Province takes $4^{\text {th }}$ place in terms of the number of registered monuments (National Heritage Board of Poland: http://www.nid.pl/pl/). This indicator ranks the discussed area in the forefront of the regions richest in number of cultural monuments. The Warmia-Masuria Province stands out not only because of its history or the number of recorded artifacts but also because of the nature of preserved elements of cultural heritage. In the article, the author discusses only the Teutonic Order State's heritage.

Natural, socio-economic and political factors had huge impact on the formation of cultural elements of the monastic state. Diversified glacial landforms, many lakes, rivers and streams, as well as access to the sea and the vast areas of undeveloped forests and woodlands made the terrain impregnable, and thus perfect for defensive settlements, towns and villages as well as economic and military organizations around the country. The list of socio-economic and political factors which influenced the development of Teutonic Order is very long, and it is impossible to discuss them entirely. However, one should mention the most 
important factors, such as: low level of political and economic organization, geopolitical location, historical volatility of the borders, political and armed conflicts, wars, trade routes, colonization based on German law, relationships with neighbors, monks' contacts with Western Europe and many more. The author points out that the Teutonic Knights during their conquests and war campaigns were in Poland perceived as invaders and murderers who had a devastating effect on the land. However, the author emphasizes that it is only part of the truth. It is believed that the contemporary Europe owes a lot to the Teutonic Knights, mainly in the field of economy, settlement, town planning, architecture, law, trade and culture. The monks introduced the conquered lands to the new Western political, economic and cultural patterns, which gradually expanded into neighboring countries.

These processes were not always carried out peacefully, especially at the beginning of the formation of the monastic state on the Baltic Sea. The Order was composed of the members originating from German cultural sphere. They were considered as foreigners in that part of Europe, and, moreover, they were perceived as an aggressive and expansive society. Conquered Prussian and Polish tribes greatly disliked the Teutonic Knights, which led to many animosities between the nations, and consequently numerous wars and battles were fought against them i.e. the Battle of Grunwald in 1410 - the biggest battles of medieval Europe. Moreover, Prussian nobles and knights established in Chełmno Land an organization - the Lizard Union which goal was to combat the Teutonic Knights. Many rebuilt networks of Knight's settlements were preserved to this day, but the vast majority of in cruda radice towns and villages are completely new. In the cities there are also visible fragments of medieval routes, historic tracking spatial layouts, as well as architectural elements of castles, churches or fragments of city walls, moats, bridges etc. It should be acknowledged that initially only the Teutonic Knights colonized conquered territories, erected architectural objects, and set villages and towns' privileges. Only with time, individual bishops, councils of some cities and diocese's authorities located in the analyzed area (Bishopric of Samland, Warmia, Pomesania and Culm) were involved in these activities (Wysocki ed., 2009). However, the architectural and urban projects undertaken by monks remained under a strong influence of the monastic order.

A Gothic brick, found present today in the northern Poland landscape, apart from wood and to a lesser extent, field stone, was the main building material of a medieval architecture of the monastic state (Arszyński, 2000). Rock materials of good quality that were suitable for construction, in addition to material disposed by the glacier, were rare on the south coast of the Baltic Sea. Consequently the constructors used rich resources of clay and sand. Brick was used for the construction of churches, city walls and castles, farm buildings, town halls, and 
thereafter, the residential urban constructions ${ }^{1}$. Dense, well-connected network of brick Gothic castles and development of the conventual castle was undoubtedly the greatest achievement of the Teutonic Order ${ }^{2}$. The Malbork Castle, the seat of the great masters and religious capital of the country (currently located in the Pomerania Province, near the Warmia-Masuria Province) is quite a unique place inscribed in UNESCO's World Heritage Site. The Teutonic Order became greatly skilled in the field of urban planning. The Order constructed unique spatial layouts of medieval towns in this part of Europe, which are nowadays visible in Culm, Torun (also on the list of UNESCO), Gdańsk, Elbląg and Olsztyn (WarmiaMasuria Province).

\section{Teutonic Knights on Polish and Prussian territories}

The Teutonic Knights ${ }^{3}$ were sent to Poland by Duke Konrad I of Masovia, who brought the monks to help fight against the pagan Prussian tribes. The first grants for the Order date back to 1225 when the Knights received Chełmno Land from the Duke Konrad I (Achremczyk, 2008, 12).

The support of the German dynasty, connections with Western Europe, armed expeditions, as well as excellent diplomatic and cunning skills allowed the Order to quickly conquered terrains on the southern coast of the Baltic Sea. In 1273 the Teutonic Knights conquered the Prussian territories. Ten years later they dominated the area of Sudovia where the Order established the monastic state, known as Prussia. Gradually they expanded to the north and west, and in 1309 the new headquarters of the Order was established in Malbork. Soon after conquering new territories the Order began to establish itself as a state. At the beginning of the fourteenth century the Prussian lands were depopulated and destroyed in regional conflagration. Consequently, the Teutonic Knights began to establish their settlement on a conquered land leaving the local people displaced. In their place settlers from the area of Germany and Poland were brought. First castles and new

${ }^{1}$ Brick houses at the end of the Middle Ages until the end ot the eighteenth century were built only in Elbląg and Braniewo. In the cities dominated wooden buildings (Wysocki ed., 2009).

${ }^{2}$ Areas located on the Vistula Lagoon are considered to be the cradle of this type of construction (Arszyński, 2002, 129).

3 The official name of the Teutonic Order in Poland was the Order of Brothers of the German House of Saint Mary in Jerusalem. The Order was established in 1198 and it was founded by the burghers of Bremen and Lübeck as a result of the transformation of the brotherhood which took place during the Siege of Acre of the Third Crusade. The Order, supported by the German dynasty, came into a possession of number of estates in European countries (Musiaka, 2013 for: Dygo, 2008, 54 [in:] Bishop, Czaja ed., 2008). 
cities began to form local government. Initially, cities were established based on the Magdeburg Law, whereas villages followed the Prussian privileges. These regulations were quickly replaced by a local modification of the law, especially by the Culm Law (Musiaka, 2013). Most of the cities founded in the twelfth and fourteenth centuries were fortified and exceptionally regular which can be explained by the destruction of former settlements and advancement of measuring tools imported from Germany. The network of urban settlements was a grid of points distant from each other about 25-30 km (Kulesza, 2011, 138). A new division of the church administration was established by new parishes and churches (Biskup, 2013, Radzimiński, 2013). The Teutonic Knights founded about 1400 villages and nearly 100 cities until the mid-fourteenth century ${ }^{4}$ (Wysocki ed. 2006, 29). The farthest east conquered territories were left as void settlement frontier.

The monastic state was growing rapidly in strength. Significant revenues were derived from commercial brokerage between Western Europe and Poland, Baltic countries and Eastern Europe. Trade was located mainly in the large cities of the Hanseatic League, i.e.: Gdańsk, Toruń, Elbląg. Preferential legal regulations encouraged German colonists to settle the territory of Prussia. As a consequence, the monastic state has become one of the best economically and administratively organized in Europe. The glory peak of the Order fell during the reign of Grand Master Winrych von Kniprode (1352-1382) ${ }^{5}$. Rebellions of Prussian towns as well as battles with Poland and Lithuania contributed to the collapse of the monastic state, which eventually was secularized in 1525 .

\section{Characteristics of the Teutonic Order State's cultural heritage. Urban planning and architecture}

There are many artifacts of the Teutonic Order legacy, which the contemporary society inherited from the past generations. Most important monuments of the urban planning and architecture of Warmia-Masuria Province ${ }^{6}$ were erected until 1525, and they include historic urban systems, castles, churches, town halls and fortifications, erected in 1525, the.

Spatial layouts of cities. Majority of cities established within the Order

\footnotetext{
${ }^{4}$ According to Kulesza, there were 96 cities settled to 1525 in the Teutonic Order (Kulesza, 2011, 139).

5 The monastic state consisted of around $58,000 \mathrm{~km}^{2}$, including the whole Kingdom of Prussia - 38,500 km², Gdańsk Pomerania - 14,850 $\mathrm{km}^{2}$ and Chełmno Land- 4,650 km² (2013 Musiaka for: Achremczyk, 2008, 21).

${ }^{6}$ The analysis focuses only on the monuments registered on the list of immovable monuments of Warmia-Masuria Province. The monuments registered on the archaeological sites were not taken into account.
} 
were new in cruda radice settlements. Irregular settlements around the castles, which resembled gothic Medieval cities, were established until the mid-thirteenth century. Usually these settlements were subject to the German law. The development of colonization and establishment of new urban centers with regular market, town hall, parish church and its fortifications (wooden or brick) date back to the fourteenth century, onwards. Settlements in the area were established according to the Magdeburg Law. The law, however, has been modified and adapted to fit local conditions and began to be known as the Culm Law (Czaja, 2000, Wysocki ed., 2009, 87, Kulesza, 2011).

Despite considerable spatial transformations of Prussian towns, the vast majority of them were of medieval origin. Fires, modernization of urban centers in the seventeenth and nineteenth century, economic development, population growth and later on development of railroads, automotive industry, destruction of both world wars, the post-war reconstruction, modernization of transportation routes and spatial systems as well as contemporary architectural and urban modifications had the greatest impact on the shape of spatial transformations of medieval settlements.

There are many interesting examples of medieval urban planning in the Warmia-Masuria Province (Figure 1, Figure 2).

Undoubtedly, Elbląg's urban planning (Figure 1) from 1246 distinguishes itself from other towns of the region. It's spatial layout, later expanded by additional elements, resembles a typical port city, such as Lübeck (KrantzDomasłowska 2013). Pasłęk, which was populated by the Dutch settlers (German name - Preusisch Holland), is another example of a unique 1297 settlement in the area. The settlement was divided into three zones - public, residential, commercial plus the castle. Nidzica, established in 1381, is considered to be an example of the so-called monastic city with regular geometric layout. Warmia's largest citiy Olsztyn, settled in 1353, which consisted of two market places, resembles very interesting spatial arrangement (Czubiel, Domagała, 1969 Wysocki ed., 2009, Kulesza, 2011). cities.

Figure 2 presents the analyzed urban planning of Warmia-Masuria Province

Castles. Until the end of the thirteenth century the Teutonic Knights erected wooden forts and watchtowers. Wood was not only cheap but also an easily accessible building material which allowed builders quick construction of buildings, because it did not require knowledge of specialized building techniques. Thereafter, they began to use brick instead. The Order's brick castles had quadrilateral shape with an inner courtyard and one or several castle boroughs of economic and military functions. The medieval castles of the Teutonic Knights as well as chapters or bishops had several functions i.e.: military, economic, administrative or monastic and sometimes judicial, residential or cultural etc. 
Figure 1: The spatial arrangement of: Elbląg, Olsztyn, Pasłęk, Nidzica, Source: Steinbrecht 1910, Chodkowska 2004 for: Wünsch in: C. Wünsch. Die Bau und Kunstdenkmaler der Stadt Allenstein, Konigsberg 1933, 34, igrek.amzp.pl, Musiaka 2013 for: Czubiel, Domagała 1969

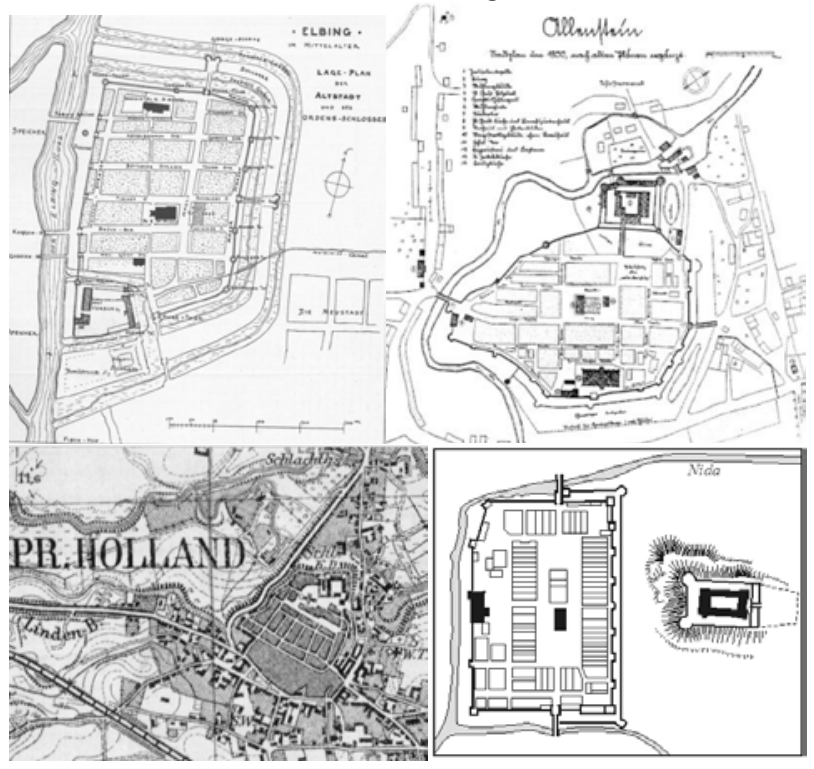

Figure 2: Examples of fine medieval architecture in the former Teutonic State Order: Castle of Warmian Bishop's in Lidzbark Warmiński, Defence church of Saint George in Kętrzyn, Town Hall in Pasłęk, medieval city gate in Bartoszyce

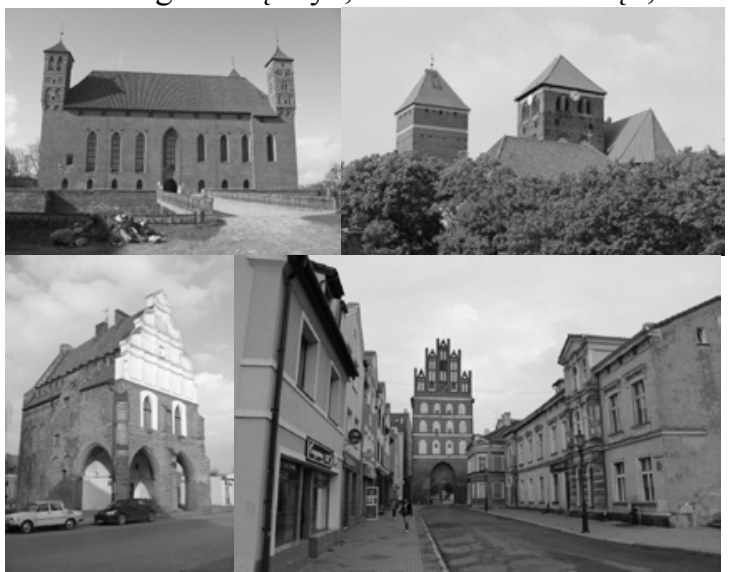

Source: author 
Unique, dense network of castles, erected at a distance of typically 20-30 $\mathrm{km}$ (one day away), was a typical form of European unification, although, spatial relations of castles and towns were different from one another (Czubiel, Domagała, 1969, Musiaka, 2013) from completely separated ones to complex, closely related defense systems.

Churches. All sacral building erected in Warmia-Masuria Province were modeled on cathedrals. They differed depending on the diocese. Warmia used the cathedral in Frombork a its model; the cathedral in Kwidzyn, which incorporated elements of Malbork chapel, was a model for the Powiśle Region, whereas the architecture of the parish church in Elbląg was influenced by the architecture of Gdańsk.

Brick sacral monuments were erected in the sixteenth century on the Eastern Masuria. Interestingly, the Gothic style buildings were built until the seventeenth century (Wysocki ed., 2009, 125-128). Churches in the cities were located near the corners of the markets, either in the quarter or directly at the building line of fortifications.

City Halls. Town halls were placed in the center of the medieval markets or, if there were no typical market squares, they were built along major thoroughfares. Medieval town halls are preserved in Morąg, Pasłęk, Górowo Iławeckie, Orneta, Olsztyn.

Fortifications. Initially, towns were surrounded by wooden-brick fortifications and moats. However, later constructions, which protected the city against invaders, were brick with a stone foundation. City walls, turrets, towers as well as gates performed its original function until the seventeenth and eighteenth century. Afterwards, they were adapted as residential areas. Unfortunately, many of them were demolished in the nineteenth century (Wysocki ed., 2009). Some cities did not have masonry fortifications and were so called "open cities".

Medieval monuments of Warmia-Masuria Province as well as Powiśle Region perform many functions depending on their state of conservation, usage, forms of ownership, location as well as other factors. Religious monuments, for example, which are supervised by local parishes, have the most transparent legal status. Military facilities are subject to different and more strict regulations. Consequently, some of the medieval monuments are adapted to hotels (from four star luxury hotels to small, two-star hotels or guest rooms), others to restaurants and sometimes museums. If monuments are administered by local governments, they are adapted to libraries, community centers, home offices etc. In some cases, castle rooms are rented by associations or other local organizations. The monofunctional castles usually become museums or hotels, whereas the multi-functional ones are often adapted to offices (Musiaka, 2013). Preserved Gothic town halls perform their original functions (Orneta, Górowo Iławeckie) or are used for public purposes (e.g. the library in the Old Town Hall in Olsztyn and Pasłęk or cultural center, tourist information in the town hall in Morag). There are not many remains 
of the old fortifications, the ones which preserved, the so called 'permanent ruin', are often at the site of former medieval walls or moats, and they decorate squares or parks, whereas, preserved towers and gates are within cultural institutions, offices of local associations or tourist information.

\section{Conclusion}

At the end of this part of the article, it is worth to mention that in 2013 in Działdowo town hall (a city founded by the Teutonic Knights) the great master of the Teutonic Order from Vienna - Bruno von Plater opened the first Interactive Museum of Teutonic State Order in Poland ${ }^{7}$. The museum enjoys considerable popularity among tourists from Poland and abroad.

\section{References}

ACHREMCZYK, S. 2008. Między Wisłą a Niemnem: szkice historyczne. Olsztyn: Ośrodek Badań Naukowych im. Wojciecha Kętrzyńskiego. ISBN 9788360839171. p. 350.

ARSZŃSKI, M. 2000. Zamki i umocnienia krzyżackie. In. Państwo zakonu krzyżackiego $w$ Prusach. Podziaty administracyjne $i$ kościelne $w$ XIII-XVI wieku. ed. Z.H. Nowak, co. R. Czaja. Toruń: Wydawnictwo Naukowe Uniwersytetu Mikołaja Kopernika. ISBN 838-76-392-65. p. 29-43.

ARSZYŃSKI, M. 2002. Na marginesie najnowszego monograficznego opracowania problematyki historycznej i architektonicznej krzyżackich zamków konwentualnych w Prusach. In. Zapiski Historyczne. ISSN 0044-1791. 2002. Vol. LXVII, No. 1. p. 125-143.

BISKUP, M. 2013. Parafie w państwie krzyżackim. In. Państwo zakonu krzyżackiego $w$ Prusach. Podziały administracyjne $i$ kościelne $w$ XIII-XVI wieku. ed. R. Czaja. R. Radzimiński. Toruń: Wydawnictwo Naukowe Uniwersytetu Mikołaja Kopernika. ISBN 978-83-231-3073-4, p. 129-149.

CHODKOWSKA, W. 2004. Stary ratusz w Olsztynie czyli historia w dokumentach i budowli. In. Wiadomości konserwatorskie [online]. 2004, vol. 15. p. 26-32. [cit. 2014-10-09]. Available at: <http://www.nid.pl/pl/ Dla_wlascicieli_i_zarzadcow/opieka-nad-zabytkami/dobre-praktyk/Chodkows kaW_StaryRatusz.pdf>. P-ISSN 0860-2395.

CZAJA, M. 2000. Miasta i ich posiadłości ziemskie w państwie zakonu krzyżackiego w Prusach. In. Państwo zakonu krzyżackiego w Prusach. Podziały administracyjne i kościelne $w$ XIII-XVI wieku. ed. Z.H. Nowak, co. R. Czaja. Toruń: Wydawnictwo Naukowe Uniwersytetu Mikołaja Kopernika. ISBN 83876-392-65. p. 44-65.

\footnotetext{
${ }^{7}$ http://muzeum.dzialdowo.pl/
} 
CZUBIEL, M. - DOMAGAŁA, T. 1969. Zabytkowe ośrodki miejskie Warmii i Mazur. Olsztyn: Wydawnictwo Pojezierze. p. 327.

DYGO, M. 2008. Początki i budowa władztwa zakonu krzyżackiego (1226-1309). In. Państwo zakonu krzyżackiego w Prusach. Wladza i spoleczeństwo. M. Biskup. R. Czaja. Warszawa: Wydawnictwo Naukkowe PWN. ISBN 9788301155261. p. 53-104.

http://muzeum.dzialdowo.pl/ [cit. 2014-13-09].

http://igrek.amzp.pl/ [cit. 2014-20-08].

http://www.nid.pl/pl/ [cit. 2014-05-09].

KULESZA, M. 2011. Zagadnienia morfogenezy i rozplanowania miast średniowiecznych w Polsce. Łódź: Wydawnictwo Ibidem. p. 360. ISBN: 97883-62331-11-6.

MUSIAKA, Ł. 2013. Funkcja turystyczna średniowiecznych zamków i jej wpływ na miasta Pomorza, Warmii i Mazur. Łódź: Wydawnictwo Uniwersytetu Łódzkiego. 201 p. ISBN 978-83-7969-001-5.

RADZIMIŃSKI, A. 2013. Podziały kościelne w Prusach. In. Zakon krzyżacki w Prusach $i$ Inflantach. Podziały administracyjne $i$ kościelne $w$ XIII-XVI wieku. ed. R. Czaja. R. Radzimiński. Toruń: Wydawnictwo Naukowe Uniwersytetu Mikołaja Kopernika. ISBN 978-83-231-3073-4. p 107-128.

STEINBRECHT, C. 1910. Preussen zur Zeit der Landmeister. Beitraege zum Baukunst des Deutschen Ritterordens. Berlin: Verlag von Julius Springer. p. 132.

WYSOCKI, J. Ed. 2009. Dziedzictwo kulturowe Warmii-Mazur-Powiśla. Stan zachowania, potencjały i problemy. Olsztyn: Warmińsko-Mazurskie Biuro Planowania Przestrzennego. ISBN 83-915022-2-8. p. 422.

\section{Lukasz Musiaka, Ph.D.}

Department of Historical Geography and Cultural Heritage

Faculty of Geographical Sciences, Univeristy of Lodz

Kopcinskiego 31 str., 90-142 Lodz, Poland

E-mail: Musiaka@wp.pl 